\title{
RESEARCH NOTE \\ The effects of centrifugal pruning on fruiting structure production in Royal Gala apples
}

\author{
María Dolores Raffo, Rodolfo Rodríguez, and Lucía Mañueco \\ Instituto Nacional de Tecnología Agropecuaria (INTA), Estación Experimental Alto Valle. CC 782, CP \\ 8332, General Roca, Provincia de Río Negro, Argentina.
}

\begin{abstract}
M.D. Raffo, R. Rodríguez, and L. Mañueco. 2011. The effects of centrifugal pruning on fruiting structure production in Royal Gala apples. Cien. Inv. Agr. 38(2): 227-232. Proper sunlight distribution in the tree canopy during the fruit-bud initiation period could increase the number of fruits and the quality of fruit development in the following year. Through winter pruning, it is possible to remove all side structures developed at the center of the tree and on the undersides of the branches. In the following spring, this pruning method produces a tube-shaped area in the canopy center that improves the penetration and distribution of light from the central axis to the canopy periphery. This approach produces a better light level at the sites where fruit-bud initiation occurs. An experiment was performed on apples cv. Royal Gala grafted on EM 9 to quantify the benefits of centrifugal pruning for return bloom. The Royal Gala/EM9 combination shows a high production potential, and the trees produce a large quantity of fruit structures. The results obtained during two consecutive vegetative seasons showed the positive influence of this extinction practice, with higher numbers of fruit structures on the treated trees than on conventionally pruned trees.
\end{abstract}

Keywords: Apples, floral induction, fruit structures.

\section{Introduction}

The balance between vegetative development and fruiting is fundamental for orchard profitability. Light is a perpetual theme in the study of canopy architecture in fruit trees owing to its role in photosynthesis, its influence on the development of leaf morphology, its effects on floral differentiation and fruit set, and its importance for fruit development and quality (Rom, 1991).

Received March 10, 2010. Accepted February 6, 2011. Corresponding author: doloresraffo@correo.inta.gov.ar
In young and mature apple orchards with open canopy development and good light exposure, yield increases linearly with the interception of photosynthetically active radiation (PAR) (Lakso, 1984). Production yields and quality generally decline in trees developing dense canopies or in high-density plantation systems. This decline occurs because of poor light distribution in the center of the canopy, especially if an unfavorable distribution of light is present at the beginning of the season, as it is in apple trees (Lakso and Corelli Grappadelli, 1993).

Increases in the quantity of light incident on the canopy will favor floral induction processes, 
which produce a metabolic change in vegetative buds. Therefore, the quantity and quality of floral structures in the following vegetative cycle are regulated. The elimination of fruiting structures would favor light distribution and the naturally occurring return bloom (Lauri et al., 1997, 1998; Wünsche and Lakso, 2000). However, lower values of light intensity increase the likelihood that apple fruits $8-30 \mathrm{~mm}$ in diameter will fall from the tree (Byers et al., 1991). Likewise, shading by the canopy produces diminished photosynthesis (Burnside and Bhöning, 1957; Rom, 1991), flowering (Lauri et al., 1996), fruit set (Lauri et al., 2004), fruit size (Raffo Benegas et al., 2004; Rodríguez and Raffo, 2006) and fruit coloration (Raffo Benegas et al., 2006), and increases the susceptibility to diseases during storage (Flore and Lakso, 1989).

The principles of classic pruning prioritize concepts based on structural models, ignoring physiological aspects of great importance (Lauri et al., 1998). Different growth habits characterize behaviors within species and even within each variety (Lauri et al., 1996; Rodríguez and Rodríguez, 1997). It has been shown that light redistribution and fruit quality redistribution from the canopy center to the canopy periphery is improved by eliminating vegetative or fruit structures through the insertion of structural branches in the tree axis with axis. This approach involves the application of the principles of artificial extinction (centrifugal pruning) (Raffo Benegas et al., 2004). The light distribution obtained using this method is the inverse of that produced by classic pruning.

The objective of this work was to evaluate the effect of centrifugal pruning on the fruiting of apples cv. Royal Gala by improving light penetration to the canopy, where the process of floral induction occurs.

\section{Materials and methods}

\section{Vegetal material and experimental design}

This work was performed in a commercial orchard with 12-year-old apples, cultivar Royal
Gala grafted on EM9, grown on a trellis with a central axis. Apples, cultivar Pink Lady, arranged in complete rows of equal training system were used as the pollen source. The gravitational irrigation furrow system was used.

Twenty homogeneous trees were selected based on their vegetative development. Centrifugal pruning was applied to 10 randomly selected trees during the winter. All the lateral structures on the main branches located in the first $30 \mathrm{~cm}$ from the axis of each tree were manually eliminated. The other 10 trees were conventionally pruned as a control.

In December, after centrifugal pruning, 10 fruiting structures (flower buds) facing northward from the trellis and 10 facing southward were identified with plastic labels in each of the 20 trees selected for the test. During January, after the official authorization for the harvest of the variety, each marked structure was individually analyzed to determine its development into a fruit bud or vegetative bud as well as its insertion in bags, spurs or limbs through the observation of morphological traits. During January in the second year of the test, the evaluation of the same marked structures was repeated using the same criteria.

\section{Radiation measurements}

Quantum sensors with data loggers (Cavadevice $\AA$, Argentina) were used to characterize the photosynthetically active radiation (PAR). Two data loggers with sensors adjusted horizontally and upwards were placed at the canopy center in each treatment (centrifugal pruning and control). The data were recorded every 15 minutes during the months of crop growth and until harvest, and the radiation was expressed in $\mu \mathrm{mol} \mathrm{m}{ }^{-2} \mathrm{seg}^{-1}$.

\section{Design and statistical analysis}

A complete randomized design consisting of two treatments and 10 replicates (trees) was used. The data were obtained from 20 fruiting structures on each tree (10 on the north side and 10 on the south side). 
The sequential development of the fruiting structures after two consecutive years was statistically evaluated by an analysis of variance (ANOVA). Tukey's test was used for comparisons of means at a 5\% significance level. A oneway ANOVA was used for the aggregate values of the radiation data. Both absolute and proportional values relativized to the incident PAR) were analyzed using a 5\% significance level (Stat Soft, 2005).

\section{Results and discussion}

The vegetal material developing near the insertion of the lateral branches in the trunk was removed by centrifugal pruning (Figure 1B). In contrast, the internal vegetative growth remained in the plants in the conventional-pruning control (Figure 1A). The experimental treatment involved a higher penetration of the photosynthetically active radiation to the canopy center, relative to the PAR levels in the control (Figure 2).

The average daily accumulated PAR in the centrifugal pruning treatment was significantly higher than the radiation accumulated in the control (Table 1). The daily accumulated proportion relative to the incident radiation was $17.28 \%$ in the centrifugal pruning treatment. This proportion was significantly lower in the control (4.62\%) (Tukey HSD test, $\mathrm{P}=0.00001)$.

The radiation at the canopy center is usually higher on cloudy days than on completely clear

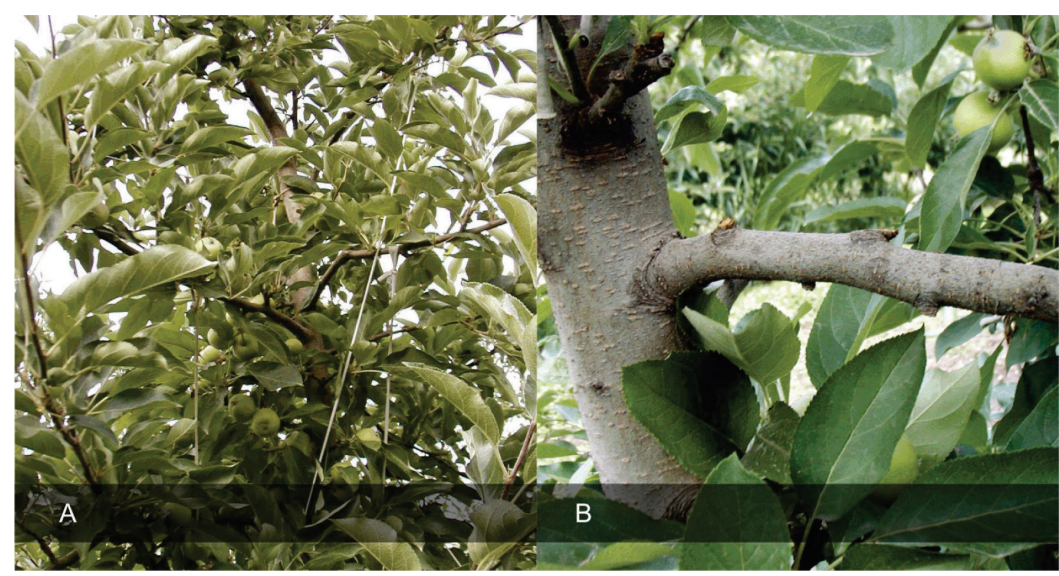

Figure 1. A) Control treatment with conventional pruning. Internal vegetative growth was observed within the plant. B) Treatment with centrifugal pruning. Notably, plant material has not developed in the area of insertion of the lateral branches or on the trunk.

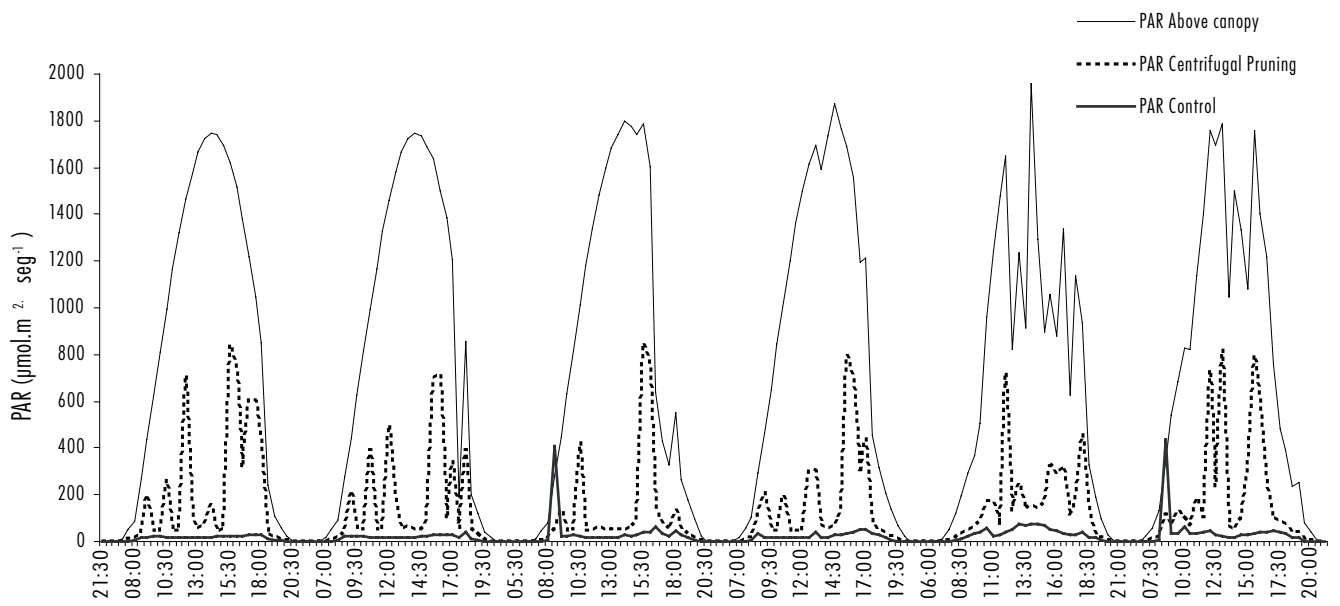

Figure 2. Photosynthetically active radiation (PAR) profiles for six representative days during summer. (一) above the canopy, (.....) within the canopy of the centrifugal pruning treatment and $(-)$ within the canopy of the control. 
days because of the higher proportion of diffuse radiation in the environment (Marini and Barden, 1982). This property was observed more clearly in the control, where the incident radiation reaching the canopy center on cloudy days was twice that found for sunny days (Table 1). The percentage of incident radiation in the centrifugal pruning treatment was not affected by the presence of clouds.

The extinction practice stimulated more frequent differentiation of fruit buds during the two seasons of study, whereas twice as many wooden buds were observed in the control trees compared with the trees with centrifugal pruning (Table 2). The large number of fruit buds observed in the centrifugal pruning treatment resulted from a higher proportion of spurs. The fruiting shoots were maintained at the same level in both treatments (Table 2). This finding is consistent with the observations of Lauri et al. (2004), who determined that centrifugal pruning in apples increased the flowering return and tended to increase the bag over bag phenomenon.
The structures in the north-facing and southfacing sectors of the canopy were evaluated with the following results. The beneficial effect of the extinction was evident from the increases in the proportion of spurs on the north side and the proportion of flower limbs on the south side. The proportions of spurs and flower limbs on the north and south sides in the centrifugal pruning treatment were similar, whereas the proportion of flower limbs was lower on the south side than on the north side in the control (Table 3). The proportion of wooden buds (simple limbs) was higher in the control than in the centrifugal pruning treatment in both sectors (Table 3 ). These results confirm the harmful effects of the redistribution of lower amounts of light in the canopy center during floral induction in the absence of centrifugal pruning. In cherry, a balance between vegetative and reproductive growth with stable production through time was achieved by centrifugal pruning over a period of years (Claverie and Lauri, 2005), whereas in another study conducted in apples cv. Galaxy, return bloom and fruit size increased after two

Table 1. Cumulative, cumulative/day and average levels of photosynthetically active radiation (PAR) measured inside the canopy of Royal Gala apple trees in the centrifugal pruning treatment and the control during representative sunny and overcast days.

\begin{tabular}{|c|c|c|c|c|c|c|}
\hline & \multicolumn{2}{|c|}{$\begin{array}{l}\text { PAR accumulated } \\
\left(\mu \mathrm{mol} \mathrm{m}-2 \mathrm{seg}^{-1}\right)\end{array}$} & \multicolumn{2}{|c|}{$\begin{array}{l}\text { PAR } \\
(\%)\end{array}$} & \multicolumn{2}{|c|}{$\begin{array}{l}\text { PAR accumulated/day } \\
\quad\left(\mu \mathrm{mol} \mathrm{m}-2 \mathrm{seg}^{-1}\right)\end{array}$} \\
\hline & $\begin{array}{l}\text { Centrifugal } \\
\text { pruning }\end{array}$ & Control & $\begin{array}{c}\text { Centrifugal } \\
\text { pruning }\end{array}$ & Control & $\begin{array}{c}\text { Centrifugal } \\
\text { pruning }\end{array}$ & Control \\
\hline Overcast day & 4232.5 & 944.2 & 20.52 & 4.6 & 2279.12 & 1142.02 \\
\hline Sunny day & 5499.5 & 456.1 & 21.6 & 1.79 & 3528.8 & 924.1 \\
\hline
\end{tabular}

Table 2. Development of wooden and fruit buds, spurs and fruiting shoots in apple cv. Royal Gala/EM 9 apple with or without centrifugal pruning after two years. Values are expressed as percentages of the total number of structures assessed.

\begin{tabular}{|c|c|c|c|c|}
\hline Treatments & Fruit buds & Wooden buds & Spurs & Fruiting shoots \\
\hline Centrifugal pruning & $42.1 \mathrm{a}$ & $7.9 \mathrm{a}$ & $25.4 \mathrm{a}$ & $16.7 \mathrm{a}$ \\
\hline Control & $35.0 \mathrm{~b}$ & $15.0 \mathrm{~b}$ & $18.3 \mathrm{~b}$ & $16.7 \mathrm{a}$ \\
\hline
\end{tabular}

Values in the same column followed by the same letter are not significantly different at the $5 \%$ level (Tukey test). 
years of extinction or centrifugal pruning (Lauri et al., 2007).

Owing to its growth and fruiting habits, the Royal Gala variety has a lower tendency for alternate production ("alternate bearing") than other varieties like Red Delicious, especially their Golden Delicious or Fuji spur clones. The combination of Royal Gala with a dwarfing rootstock like EM9 results in a foliar mass that is very permeable to light penetration (Raffo Benegas et al., 2006). Therefore, a better response to this practice might be expected in combinations with more vigorous rootstocks that produce a higher canopy volume and a dense leaf area. A better response might also be expected in varieties that tend to exhibit alternate production, like those mentioned above.

The centrifugal pruning improved the PAR distribution within the canopy. Consequently, fruit-producing structures were more frequent in the following seasons. This result, evident from the higher proportion of spurs and the lower proportion of wooden buds, may be attributed to the improved illumination of the inner zone during floral induction.

Table 3. Influence of orientation on the effect of centrifugal pruning on the development of different Royal Gala/EM9 apple tree structures. Values are expressed as percentages of the total number of structures assessed.

\begin{tabular}{|c|c|c|c|c|c|c|}
\hline \multirow[b]{2}{*}{ Treatments } & \multicolumn{2}{|c|}{ Spurs } & \multicolumn{2}{|c|}{ Fruiting shoots } & \multicolumn{2}{|c|}{ Wooden buds } \\
\hline & North & South & North & South & North & South \\
\hline $\begin{array}{l}\text { Centrifugal } \\
\text { pruning }\end{array}$ & $12.9 \mathrm{a}$ & $12.5 \mathrm{~b}$ & $8.3 \mathrm{a}$ & $8.3 \mathrm{a}$ & $3.8 \mathrm{a}$ & $4.2 \mathrm{a}$ \\
\hline Control & $7.1 \mathrm{~b}$ & $11.3 \mathrm{~b}$ & $11.3 \mathrm{~b}$ & $5.4 \mathrm{~b}$ & $6.7 \mathrm{~b}$ & $8.3 \mathrm{~b}$ \\
\hline
\end{tabular}

Values in the same column followed by the same letter are not significantly different at the $5 \%$ level (Tukey test).

\section{Resumen}

M.D. Raffo, R. Rodríguez y L. Mañueco. 2011. Incidencia de la poda centrífuga sobre la producción de estructuras fructíferas de manzanas Royal Gala. Cien. Inv. Agr. 38(2): 227-232. Una correcta distribución de la luz en el interior del árbol frutal durante la inducción floral puede mejorar el nivel de fructificación del año siguiente. Mediante la eliminación de todas las estructuras laterales desarrolladas sobre las ramas principales en los primeros $30 \mathrm{~cm}$ a partir de su inserción sobre el eje central del árbol (poda centrífuga), realizada durante el período de reposo invernal, se genera una zona en forma de "tubo". Esta abertura en la copa del árbol asegura una distribución más uniforme de la luz, que se distribuye en forma envolvente, "centrífuga", desde el eje central hacia la periferia del árbol con una mejor llegada a los sitios donde se encuentran las yemas pasibles de ser inducidas a yema floral. El objetivo de este trabajo fue evaluar el efecto de la poda centrífuga sobre la fructificación en manzanos cv. Royal Gala. La experiencia se realizó en manzanos, cv. Royal Gala, injertados sobre el portainjerto EM9, para evaluar los beneficios de la poda centrífuga sobre el retorno de floración. Royal Gala/ EM9 es una combinación que asegura un elevado potencial productivo y consecuentemente una gran disponibilidad de estructuras fructíferas. Los resultados obtenidos durante dos ciclos vegetativos consecutivos evidenciaron el efecto positivo de la práctica de extinción sobre la calidad de las estructuras fructíferas, al verificarse en los árboles tratados una mayor tendencia a la fructificación.

Palabras clave: Estructuras fructíferas, inducción floral, manzanos. 


\section{References}

Burnside, C.A., and R.H. Bhöning. 1957. The effect of prolonged shading on the light saturation curves of apparent photosynthesis in sun plants. Plant Physiol. 32: 61-63.

Byers, R.E., D.H. Carbough, C.N. Presley, and T.K. Wolf. 1991. The influence of low light on apple fruit abscission. J. Amer. Soc. Hort. Sci. 66: 7-17.

Claverie, J., and P.E. Lauri. 2005. Extintion training of sweet cherries in France - Appraisal after six years. Acta Hort. 667: 367-372.

Flore, J.A., and A.N. Lakso. 1989. Environmental on physiological regulation of photosyntesis in fruit crop. Hort. Rev. 11: 111-157.

Lakso, A. 1984. Leaf area development patterns in young pruned and unpruned apple trees. J. Amer. Soc. Hort. Sci. 109: 861-865.

Lakso, A., and L. Corelli Grappadelli. 1993. Implications of pruning and training practices to carbon partitioning and fruit development in apple. Acta Hort. 332: 231-240.

Lauri, P.E., J.M. Lespinasse, F. Delort, E. Térouanne, and R.O. Rodríguez. 1996. Analyse des branches fruitières et régularité de fructification. Fruit et Légumes 147: 26-28.

Lauri, P.E., J.M. Lespinasse, and L. Fouilhaux. 1997. Vers un meilleur controle de la fructification. L'Arboriculture Fruitière 510: 37-42.

Lauri, P.E., M.H. Meaux, and E. Terouanne. 1998. L'alternance de production chez le pommier (Malus domestica Borkh.) Approche descriptive sur la branche fruitière de c.v. Braeburn. 11 $1^{\mathrm{ème}}$. Colloque sur les Recherches Fruitières. Montpellier, France. 211-214.

Lauri, P.E., M. Williaume, G. Larrive, and J. Lespinasse. 2004. The concept of centrifugal training in apple aimed at optimizing the relationship between growth and fruiting. Acta Hort. 636: 35-42.
Lauri, P.E., X. Crété, and G. Ferré. 2007. Centrifugal training in apple - appraisal of a two-year experiment on 'Galaxy' in Southeast France. Acta Hort. 732: 391-396.

Marini, R., and J. Barden. 1982. Light penetration on overcast and clear days, and specific leaf weight in apple trees as affected by summer or dormant prunning. J. Amer. Soc. Hort. Sci. 107: 39-43.

Raffo Benegas, D., R. Rodríguez, and A.P. Candan. 2004. Efecto de la poda centrífuga sobre la distribución de la luz y calidad de la fruta en manzanos cv. Royal Gala. Actas del XXVII Congreso Argentino de Horticultura. Merlo, Argentina. 27 pp.

Raffo Benegas, M.D., R.O. Rodríguez, and A. Rodríguez. 2006. Distribución lumínica en diferentes combinaciones portainjerto/variedad en manzano cv. Mundial Gala y su efecto sobre la calidad de la fruta y parámetros vegetativos. RIA 35: 53-69.

Rodríguez, R., and Rodríguez, M. 1997. Efecto de la posición y del tipo de estructuras fructíferas sobre la calidad del fruto de manzanos cv. Fuji en Río Negro y Neuquén, Argentina. Fruticultura Profesional 90: 10-12.

Rodríguez, R.O., and M. D. Raffo. 2006. Mejoramiento de la calidad de la producción del cerezo (Prunus avium) cv. Sunburst mediante la extinción manual de estructuras fructíferas. Fruticultura Profesional 156: 13-18.

Rom, C.R. 1991. Light thresholds for apple tree canopy growth and development. HortScience 26: 989-992.

Stat Soft, Inc. 2005. Statistica (data analysis software system), version 7.1. Available online at: www.statsoft.com (Website accessed October 20, 2009).

Wünsche, J.N., and A.N. Lakso. 2000. The relationship between leaf area and light interception by spur and extension shoot leaves and apple orchard productivity. HortScience 35: 1202-1206. 